\title{
PENGARUH PEMBERIAN EKSTRAK BUNGA DAN DAUN PEPAYA (Carica papaya L.) TERHADAP KADAR GLUKOSA DARAH TIKUS WISTAR (Rattus norvegicus L.) YANG HIPERGLIKEMIK
}

\author{
Frendy G. Tangkumahat ${ }^{1)}$, Johnly A. Rorong ${ }^{1)}$, Feti Fatimah ${ }^{1)}$ \\ ${ }^{1)}$ Program Studi Kimia FMIPA Universitas Sam Ratulangi \\ Frendygrenaldy25@gmail.com, rorongjhonly@yahoo.co.id, fetifatimah_unsrat@yahoo.co.id
}

\begin{abstract}
ABSTRAK
Telah dilakukan penelitian tentang Pengaruh Pemberian Ekstrak Bunga dan Daun Pepaya (Carica papaya L.) terhadap Kadar Glukosa Darah Tikus Wistar (Rattus norvegicus L.) yang hiperglikemik. Tujuan penelitian ini untuk mengetahui pengaruh ekstrak bunga dan daun pepaya terhadap kadar glukosa darah tikus wistar. Penelitian ini menggunakan metode uji toleransi glukosa. Digunakan 30 ekor tikus wistar jantan yang dibagi dalam 5 kelompok perlakuan yaitu kelompok kontrol positif (K+) diberi Air, kelompok kontrol negatif (K-) diberi Sukrosa, Ekstrak bunga pepaya dosis $150 \mathrm{mg} / \mathrm{kg}$ BB (B1), Ekstrak bunga pepaya dosis $260 \mathrm{mg} / \mathrm{kg}$ BB (B2), Ekstrak daun pepaya dosis $100 \mathrm{mg} / \mathrm{kg}$ BB (D1) dan Ekstrak daun pepaya dosis $170 \mathrm{mg} / \mathrm{kg} \mathrm{BB}$ (D2). Data diperoleh dari pemeriksaan kadar glukosa darah puasa setelah tikus diinduksi aloksan secara intraperitional dan setelah masa adaptasi selama 7 hari dan masa perlakuan selama 3 hari setelah diinduksi sediaan per oral (p.o.). Pemberian ekstrak Ethanol bunga dan daun pepaya (Carica Papaya L.) berpengaruh terhadap penurunan kadar glukosa darah tikus wistar (Ratus Norvegicus L.) yang Hiperglikemik. Dosis ekstrak bunga dan daun pepaya yang efektif dalam menurunkan kadar glukosa darah tikus yang hiperglikemia akibat diinduksi dengan aloksan adalah $260 \mathrm{mg} / \mathrm{Kg} \mathrm{BB}$ dan dosis ekstrak daun $170 \mathrm{mg} / \mathrm{Kg}$ BB atau setara dengan bunga dan daun pepaya basah $200 \mathrm{~g}$.
\end{abstract}

Kata Kunci : Carica papaya L, Kadar Glukosa Darah, Aloksan, Hiperglikemik.

\section{EFFECT OF FLOWER AND PAPAYA LEAF EXTRACT (Carica papaya L.) ON WISTAR RATS BLOOD GLUCOSE LEVEL (Rattus norvegicus L.) WHICH HYPERGL YCEMIC}

\begin{abstract}
A Research had been carried out to determine the Effect of Flower and Papaya Leaf Extract (Carica papaya L.) on Wistar Rats Blood Glucose Level (Rattus norvegicus L.) which hyperglycemic. The purpose of this research is to know the effect of flower and papaya leaf extract on wistar rats blood glucose level. This research used glucose tolerance test method. Used 30 male wistar rats divided into 5 groups of treatment that is positive control group $(\mathrm{K}+)$ given Water, negative control group (K-) given Sucrose, papaya flower extract dose $150 \mathrm{mg} / \mathrm{kg}$ BW (B1), papaya flower extract dose $260 \mathrm{mg} / \mathrm{kg} \mathrm{BW}$ (B2), papaya leaf extract dose $100 \mathrm{mg} / \mathrm{kg}$ BW (D1) and papaya leaf extract dose $170 \mathrm{mg} / \mathrm{kg}$ BW (D2). Data were obtained from fasting blood glucose examination after rats induced alloxan intraperitional and after a 7-day adaptation period and a 3-day treatment period after induced oral preparation (p.o.). The giving of Ethanol flower extract and papaya leaf (Carica Papaya L.) had an effect on the decrease of blood glucose level of Wistar rats (Ratus norvegicus L.) which Hyperglycemic. The dose of flower and papaya leaf extract is effective in lowering blood glucose levels of hyperglycemic rats induced by alloxan is dose of papaya extract $260 \mathrm{mg} / \mathrm{Kg} \mathrm{BW}$ and dose of leaf extract $170 \mathrm{mg} / \mathrm{kg} \mathrm{BW}$ or equal of $200 \mathrm{~g}$ wet papaya flowers and leaves.
\end{abstract}

Keywords: Carica Papaya L, Blood Glucose Levels, Alloxan, Hyperglycemic. 


\section{PENDAHULUAN}

Indonesia merupakan negara kepulauan yang terletak di zona khatulistiwa (tropik), beriklim tropis dan terkenal mempunyai kekayaan alam dengan beranekaragam jenis tumbuhan salah satunya buah-buahan. Sebagai makanan yang sehat, buah-buahan diperlukan oleh tubuh karena mengandung berbagai vitamin dan mineral yang bermanfaat bagi tubuh manusia. Pada umumnya bahan makanan seperti halnya buah-buahan mengandung senyawa metabolit primer yaitu karbohidrat, protein dan lipid atau lemak.

Karbohidrat sangat berperan penting dalam tubuh manusia, karena metabolisme karbohidrat berfungsi menghasilkan energi dan juga sebagai cadangan energi dalam tubuh manusia. Sukrosa merupakan karbohidrat yang tersusun dari glukosa dan fruktosa. Baik sukrosa maupun laktosa yang masuk ke dalam tubuh harus dipecah ke dalam gula pembentuknya dengan enzim $\alpha$ amilase sebelum diserap dan dipakai oleh tubuh. Konsumsi gula harus dilakukan dengan seimbang, tubuh mengatur karbohidrat yang masuk harus sama dengan energi yang dikeluarkan oleh tubuh. Selain itu, kelebihan konsumsi gula diduga dapat memicu beberapa kondisi seperti obesitas, resistensi insulin, serta naiknya tingkat kolesterol dan trigliserida. Akibatnya dapat menyebabkan gangguan metabolisme, diabetes millitus, dan penyakit kardiovaskular lainnya (Murray et al., 2009).

Gangguan metabolisme karbohidrat yang disebabkan oleh jumlah insulin yang kurang atau kerja insulin yang tidak optimal, sehingga insulin tidak bisa masuk ke dalam sel dan hanya menumpuk di pembuluh darah dapat mengakibatkan penyakit Diabetes Mellitus (DM). Menurut Corwin (2009), gangguan ini ditandai dengan kondisi hiperglikemia, dimana terjadi peningkatan kadar glukosa dalam darah (dari rentang kadar glukosa puasa normal $\quad 80-90 \mathrm{mg} / \mathrm{dL}$ sampai kadar glukosa waktu hiperglikemia 140-160 mg/dl). Menurut Shuldier (2001), menunjukkan bahwa resiko perkembangan DM, kemungkinan berkaitan dengan konsumsi makanan tinggi energi. Menurut Sukandar et al. (2008), DM disebabkan karena ganngguan metabolisme karbohidrat, lemak, dan protein yang ditandai dengan kondisi hiperglikemia.

Tanaman pepaya banyak terdapat di Sulawesi Utara, masyarakat Sulawesi Utara memanfaatkan bunga dan daun pepaya untuk dijadikan bahan makanan, dikonsumsi karena memiliki cita rasa yang khas. Tanaman pepaya banyak tumbuh subur di Sulawesi Utara karena iklim tropis yang mendukung pertumbuhan.

Berdasarkan penelitian yang telah dilakukan sebelumnya, terdapat komponen kimia pada bunga dan daun pepaya yang bermanfaat untuk kesehatan tubuh manusia. Menurut Latifah dan Syharial (2007), ekstrak aseton bunga pepaya mengandung molekul steroid. Menurut Mahatriny et al. (2014), ekstrak etanol daun pepaya mengandung senyawa alkaloid, flavonoid, dan tannin. Analisis fitokimia daun pepaya mengandung senyawa flavonoid, alkaloid, tannin, saponin, dan steroid (Ayoola \& adeyeye, 2010). Menurut Indrawati et al. (2002), bunga pepaya menunjukkan adanya golongan senyawa flavonoid, tanin, steroid/triterpenoid, dan karbohidrat.

Komponen kimia pada bunga dan daun pepaya banyak manfaat untuk kesehatan tubuh manusia. Ada pendapat masyarakat yang menyatakan bahwa penderita DM tidak baik mengkonsumsi bunga dan daun pepaya karena dapat meningkatkan kadar glukosa darah. Namun sejauh ini, belum ada penelitian tentang hal tersebut. Berdasarkan uraian di atas, peneliti tertarik untuk melakukan penelitian tentang pengaruh pemberian ekstrak bunga dan daun pepaya terhadap kadar gula darah pada tikus wistar yang hiperglikemik.

\section{METODE PENELITIAN}

\section{Waktu dan Tempat}

Penelitian ini akan dilaksanakan pada bulan Mei-Juni 2017 di Laboratorium Biokimia FMIPA Universitas Sam Ratulangi Manado dan Laboratorium Biologi FMIPA Universitas Negeri Manado.

\section{Alat dan Bahan}

Alat-alat yang digunakan dalam percobaan ini adalah peralatan gelas, oven, 
micro pipet, timbangan analitik, ayakan 65 mesh, dan suntik sonde $5 \mathrm{~mL}$,alat ukur glukosa darah yaitu GlucoDr dan GlucoDr Strip (Blood Glucose Test Meter). Sampel yang digunakan pada penelitian ini adalah serum darah tikus wistar, ekstrak bunga dan daun pepaya. Bahan-bahan kimia yang digunakan adalah Etanol, aloksan, sukrosa (gula pasir), Carboxy Methyl Cellulosa (CMC), aquades, dan pakan ternak.

\section{Preparasi Sampel}

Bunga dan daun pepaya $3200 \mathrm{~g}$ dikeringkan dengan cara diangin-anginkan dan dikeringkan dengan oven pasa suhu $50^{\circ} \mathrm{C}$ sampai menjadi simplisia.

\section{Penentuan Kadar Air}

Penentuan kadar air serbuk bunga dan daun pepaya menggunakan metode Helrich (1995).

\section{Pembuatan Ekstrak}

Sebanyak $200 \mathrm{~g}$ serbuk bunga dan daun pepaya secara terpisah dimasukkan ke dalam gelas piala $1000 \mathrm{~mL}$ dan diekstrak dengan 1 L etanol 96\% secara maserasi selama $3 \times 24$ jam. Selanjutnya ekstrak ethanol bunga dan daun pepaya disaring menggunakan kertas saring dalam Erlenmeyer $1000 \mathrm{~mL}$. Selanjutnya dievaporasi pada suhu $78 \mathrm{oC}$, dimasukkan ke dalam oven pada suhu $40 \mathrm{oC}$ selama 5 jam hingga diperoleh ekstrak kental.

\section{Pembuatan Larutan Aloksan sebagai Dosis Perlakuan pada Tikus (Maliangkay,2016)}

Dosis aloksan yang digunakan untuk tikus adalah $90 \mathrm{mg} / \mathrm{kgBB}$. Dosis sukrosa yang digunakan, dihitung berdasarkan berat badan dari masing-masing tikus, kemudian dilarutkan dalam aquades sebanyak $2,5 \mathrm{~mL}$ dan diberikan pada masing-masing tikus secara intraperitoneal (i.p.).

\section{Pembuatan Larutan Sukrosa (Kanon, 2012)}

Dosis sukrosa yang digunakan untuk tikus adalah 5,625 $\mathrm{g} / \mathrm{kgBB}$. Dosis sukrosa yang digunakan, dihitung berdasarkan berat badan dari masing-masing tikus, kemudian dilarutkan dalam aquades sebanyak $2,5 \mathrm{~mL}$ dan diberikan pada masing-masing tikus sebagai kontrol negativ (K-).

\section{Pembuatan Larutan CMC 0,5\% (Kanon, 2012)}

Sebanyak 0,5 g CMC ditaburkan dalam gelas piala yang berisi $30 \mathrm{~mL}$ air yang telah dipanaskan, selanjutnya diaduk sampai homogen. Larutan CMC dipindahkan ke labu ukur $100 \mathrm{~mL}$ dan dicukupkan volumenya dengan akuades hingga tanda tera.

\section{Pembuatan Larutan Ekstrak Bunga dan Daun Pepaya 12,6; 25,2 g/kg BB (Salma, 2013)}

Diasumsikan dosis pemakaian bunga dan daun pepaya pada pada manusia $(50 \mathrm{~kg})$ adalah $100 \mathrm{~g} /$ hari. Faktor konversi dosis dari manusia $(70 \mathrm{~kg})$ ke tikus $(200 \mathrm{~g})$ adalah 0,018 , maka dosis bunga dan daun pepaya yang diberikan kepada tikus adalah $12,6 \mathrm{~g} / \mathrm{Kg}$ BB. Dalam penelitian ini dibuat variasi dosis yaitu $100 \mathrm{~g}$ dan $200 \mathrm{~g}$ bunga dan daun pepaya untuk manusia dan bila dikonversikan ke tikus menjadi $12,6 \mathrm{~g} / \mathrm{Kg} \mathrm{BB}$ dan $25,2 \mathrm{~g} / \mathrm{Kg}$ BB. Karena yang diberikan kepada tikus bukan bunga dan daun pepaya segar melainkan dalam bentuk ekstrak maka dikonversikan lagi ke dalam bentuk ekstrak. Jadi pada empat kelompok perlakuan diberi larutan ekstrak bunga dan daun pepaya dosis $150 \mathrm{mg} / \mathrm{Kg}$ BB dan $260 \mathrm{mg} / \mathrm{Kg}, 100 \mathrm{mg} / \mathrm{Kg}$ $\mathrm{BB}$ dan $170 \mathrm{mg} / \mathrm{Kg} \mathrm{BB}$ yang setara dengan dosis bunga dan daun pepaya segar untuk tikus. Banyaknya ekstrak bunga dan daun pepaya yang digunakan, dihitung berdasarkan berat badan dari masing-masing tikus, selanjutnya dilarutkan dengan larutan CMC $0,5 \%$ sebanyak $2 \mathrm{~mL}$ dan diberikan kepada tikus secara per oral (p.o.).

\section{Pengukuran Kadar Glukosa Darah}

Sebelum percobaan 30 ekor tikus dibagi menjadi 6 kelompok dan diadaptasikan selama $7 \times 24$ jam dengan pemberian pakan ternak dan air. Selanjutnya tikus dipuasakan (tidak diberi makan, hanya diberi minum) selama 12 jam, selanjutnya ditimbang berat badan tikus. Masing-masing tikus diukur kadar glukosa darah puasa dengan cara digunting bagian ujung ekor tikus. Darah yang keluar disentukkan pada Test Strip yang telah terpasang pada alat glukometer dan dibiarkan alat mungukur kadar glukosa darah secara otomatis. Angka yang tampil pada layar dicatat sebagai kadar glukosa darah (mg/dL). 
Selanjutnya tikus diinduksi aloksan 90 $\mathrm{mg} / \mathrm{kg} \quad \mathrm{BB}$ secara intraperitional untuk menaikkan kadar glukosa darah. Induksi intraperitional dengan cara aloksan yang telah dilarutkan dengan $2 \mathrm{~mL}$ air dimasukkan ke dalam suntik $5 \mathrm{~mL}$. Selanjutnya disuntikan pada tubuh tikus tepat pada bagian pankreas. Tikus dipuasakan (tidak diberi makan, hanya diberi minum) selama 12 jam, selanjutnya ditimbang berat badan tikus dan diukur kadar glukosa darah tikus. Selanjutnya, tikus diberi sediaan per oral untuk kelompok perlakuan; kontrol positif (K-) diberi sukrosa $5,625 \mathrm{~g} / \mathrm{Kg}$ $\mathrm{BB}$, kontrol positif $(\mathrm{K}+)$ diberi air, untuk kelompok perlakuan ekstrak bunga pepaya (B) diberi ekstrak dengan dosis $150 \mathrm{mg} / \mathrm{Kg}$ BB (B1) dan $270 \mathrm{mg} / \mathrm{Kg}$ BB (B2), untuk kelompok perlakuan esktrak daun pepaya (D) diberi ekstrak dengan dosis $100 \mathrm{mg} / \mathrm{Kg} \mathrm{BB}$ (D1)dan $170 \mathrm{mg} / \mathrm{Kg} \quad \mathrm{BB}$ (D2). Induksi sediaan peroral dengan cara ekstrak yang telah disiapkan dilarutkan dengan $2 \mathrm{~mL}$ CMC $0,5 \%$, selanjutnya dimasukkan kedalam suntik sonde $5 \mathrm{~mL}$. Selanjutnya pipa yang ada pada suntik sonde dimasukkan ke dalam mulut tikus hingga mencapai lambung. Untuk kelompok perlakuan Kontrol negatif $(\mathrm{K}+)$ hanya diberi air. Selanjutnya tikus kadar glukosa darah diperiksa setelah 3 hari setelah diinduksi sedian per oral. Tikus dipuasakan (tidak diberi makan, hanya diberi minum) selama 12 jam, selanjutnya ditimbang berat badan tikus dan diukur kadar glukosa darah tikus. Semua sampel darah diambil dari vena ekor tikus dan kadar glukosa darah diukur menggunakan GlucoDr dan GlucoDr Strip (Blood Glucose Test Meter).

\section{Analisis Data (Sudjana, 1996)}

Data yang diperoleh dianalisis dengan menggunakan uji ANOVA satu arah dan uji Duncan menggunakan program statistika SPSS 20.

\section{HASIL DAN PEMBAHASAN}

\section{Kadar Air Bunga \& Daun Pepaya}

Penentuan kadar air bertujuan untuk menyatakan kandungan zat dalam tumbuhan sebagai persen bahan kering. Kadar air juga berkaitan dengan ukuran ketahanan suatu bahan dalam penyimpanan (Harjadi dalam Tresna, 2012). Kadar air menentukan stabilitas ekstrak dan bentuk sediaan selanjutnya. Syarat kadar air adalah kurang dari 10\% (DepKes RI, 1995). Kadar air dalam ekstrak yang kurang dari 10\% bertujuan untuk menghindari cepatnya pertumbuhan jamur dalam ekstrak (Soetarno dan Soediro, 1997). Kadar air bunga dan daun pepaya disajikan pada tabel 1 .

Tabel 1. Kadar Air Bunga dan Daun Pepaya

\begin{tabular}{|c|c|c|c|}
\hline Sampel & \multicolumn{3}{|c|}{$\begin{array}{l}\text { KadarAir (\%) } \\
\text { Rata-rata }\end{array}$} \\
\hline $\begin{array}{l}\text { Bunga } \\
\text { Pepaya }\end{array}$ & 1 & & 5,19 \\
\hline Daun Pepaya & $\begin{array}{l}2 \\
1 \\
2\end{array}$ & $\begin{array}{c}5,57 \\
6,21 \\
2,94\end{array}$ & 6,07 \\
\hline
\end{tabular}

Hasil perhitungan kadar air bunga pepaya diperoleh sebesar $5,19 \%$ dan daun pepaya diperoleh sebesar $6,07 \%$ dimana hasil keduanya memenuhi syarat yaitu kurang dari $10 \%$.

\section{Rendemen Bunga \& Daun Pepaya}

Pada penelitian ini proses ekstraksi dilakukan dengan cara maserasi, yaitu dilakukan dengan merendam serbuk bunga dan daun pepaya dalam larutan ethanol. Rendemen bunga \& daun pepaya disajikan dalam Tabel 2.

Tabel 2. Rendemen Ekstrak Ethanol Bunga dan Daun Pepaya

\begin{tabular}{cc}
\hline \multicolumn{2}{c}{ Rendemen (\%) } \\
\hline Bunga Pepaya & Daun Pepaya \\
\hline 12,11 & 15,67 \\
\hline
\end{tabular}

Ekstrak etanol yang didapat untuk bunga pepaya sebanyak $21,11 \%$ dan untuk ekstrak daun pepaya didapat sebanyak 15,67\%. Maserasi dipilih karena memiliki keunggulan, yakni pengerjaan yang cepat dan cara pengerjaan dan peralatan yang digunakan sederhana, relatif mudah dan murah (Samuelsson, 1999).

\section{Pengujian Efek Ekstrak Bunga \& Daun Pepaya terhadap Kadar Glukosa Darah Tikus}

Pada penelitian digunakan 30 ekor tikus. Bobot badan tikus berkisar antara 168-211 g. Tikus mengalami 3 masa yaitu; Masa Adaptasi (MA), Masa Hiperglikemik (MH), \& Masa Perlakuan (MP). MA adalah tikus disesuaikan dengan kondisi lingkungan selama 7 hari dengan pemberian pakan dan air, selanjutnya diukur kadar glukosa darah 
setelah tikus dipuasakan selama 12 jam. MH adalah tikus diinduksi aloksan dosis 90 $\mathrm{mg} / \mathrm{Kg} \mathrm{BB}$, selanjutnya diukur kadar glukosa darah setelah tikus dipuasakan selama 12 jam. MP adalah tikus pada setiap kelompok diberi; sukrosa (kelompok K-), air (kelompok $\mathrm{K}+$ ), ekstrak bunga pepaya dosis $150 \mathrm{mg} / \mathrm{kg}$ BB (kelompok B1), ekstrak daun pepaya dosis $260 \mathrm{mg} / \mathrm{kg}$ BB (kelompok B2), ekstrak bunga pepaya dosis $100 \mathrm{mg} / \mathrm{kg} \quad \mathrm{BB}$ (kelompok D1), dan ekstrak daun pepaya dosis $170 \mathrm{mg} / \mathrm{kg}$ BB (kelompok D2). Selanjutnya tikus diberi pakan dan air selama 3 hari, dan diukur kadar glukosa darah setelah tikus dipuasakan 12 jam. Tikus dipuasakan selama 12 jam dan diukur kadar glukosa darahnya. Kadar glukosa darah tikus disajikan dalam Tabel 3.

Kadar glukosa darah setelah masa adaptasi berkisar 82-97 mg/dL. Nilai ini merupakan kadar glukosa darah normal untuk tikus. Menurut Taguchi (1995), kadar glukosa darah normal tikus putih jantan adalah $<105$ $\mathrm{mg} / \mathrm{dL}$. Kadar glukosa darah tikus setelah masa hiperglikemik berkisar 174,40-193,20 $\mathrm{mg} / \mathrm{dL}$. Menurut Mailangkay (2015), tikus yang diinduksi aloksan secara intraperitional akan mengalami peningkatan kadar glukosa darah $>147 \mathrm{mg} / \mathrm{dL}$.

Tabel 3. Kadar Glukosa Darah pada Tikus

\begin{tabular}{cccc}
\hline & \multicolumn{3}{c}{$\begin{array}{c}\text { Kadar Glukosa Darah } \\
\text { (mg/dL) }\end{array}$} \\
\cline { 2 - 4 } $\begin{array}{c}\text { Kelompok } \\
\text { Perlakuan }\end{array}$ & MA & MH & MP \\
\hline K(-) & 83.88 & 174.40 & 173.60 \\
K(+) & 82.00 & 174.00 & 164.00 \\
B1 & 85.60 & 193.00 & 175.80 \\
B2 & 88.40 & 186.80 & 157.80 \\
D1 & 87.80 & 193.20 & 179.60 \\
D2 & 96.40 & 189.80 & 168.80 \\
\hline
\end{tabular}

Keterangan:

$\mathrm{K}(+)$ : Kelompok kontrol positif air

$\mathrm{K}(-)$ : Kelompok kontrol negatif sukrosa

B1: Ekstrak bunga pepaya dosis $150 \mathrm{mg} / \mathrm{kg}$ BB

B2: Ekstrak bunga pepaya dosis $260 \mathrm{mg} / \mathrm{kg} \mathrm{BB}$

D1: Ekstrak daun pepaya dosis $100 \mathrm{mg} / \mathrm{kg} \mathrm{BB}$

D2: Ekstrak daun pepaya dosis $170 \mathrm{mg} / \mathrm{kg} \mathrm{BB}$

Kadar glukosa darah tikus puasa 12 jam pada hari ke-9 setelah diinduksi dengan larutan aloksan $90 \mathrm{mg} / \mathrm{Kg}$ BB naik berkisar
$174-193 \mathrm{mg} / \mathrm{dL}$ atau meningkat 52,80\% Hasil ini sejalan dengan penelitian Maliangkay (2016), bahwa tikus yang diinduksi aloksan $90 \mathrm{mg} / \mathrm{Kg}$ BB secara intraperitional dapat menyebabkan hiperglikemia, dengan kenaikan kadar glukosa darah $>147 \mathrm{mg} / \mathrm{dL}$ dan meningkat $>50 \%$. Hal ini disebabkan aloksan merupakan salah satu agen diabetogenik yang bersifat toksik, terutama terhadap sel beta pankreas yang apabila diberikan kepada hewan uji seperti tikus akan menyebabkan hewan uji menjadi diabetes (Prameswari \& Widjanarko, 2014). Hal ini juga ditunjang oleh hasil pengamatan histopatologi (Mailangkay, 2016) dimana pulau-pulau Langerhans pankreas mulai mengecil dan ini merupakan indikasi bahwa sel-sel beta pankreas mengalami kerusakan dan gagal mensekresikan insulin yang akhirnya menyebabkan peningkatan kadar glukosa dalam darah. Menurut Szkudelski (2001) Aloksan adalah suatu senyawa yang sering digunakan untuk penelitian diabetes menggunakan hewan coba. Aloksan dalam tubuh mengalami metabolisme reduksi oksidasi menghasilkan radikal hidroksil yang sangat reaktif sehingga mengakibatkan kerusakan sel $\beta$ Langerhans. Efek ini mengakibatkan produksi insulin di dalam tubuh menurun sehingga terjadilah kondisi hiperglikemik. Hasil percobaan (setelah masa adaptasi dan induksi aloksan) menunjukkan adanya variasi kadar glukosa darah. Salah satu faktor adanya variasi kadar glukosa darah adalah karena daya tahan individu tikus yang berbeda terhadap aloksan sehingga menyebabkan kondisi awal keadaan diabetes tidak seragam (Suarsana et al., 2010).

Tabel 4. Perubahan Kadar Glukosa Darah pada Tikus

\begin{tabular}{|c|c|c|}
\hline $\begin{array}{l}\text { Kelompok } \\
\text { Perlakuan }\end{array}$ & $\begin{array}{c}\Delta \text { Glukosa } \\
\text { Masa } \\
\text { Hiperglikemik } \\
(\%)\end{array}$ & $\begin{array}{c}\Delta \text { Glukosa } \\
\text { Masa } \\
\text { Perlakuan } \\
(\%)\end{array}$ \\
\hline $\mathrm{K}(-)$ & 51.90 & -0.46 \\
\hline $\mathrm{K}(+)$ & 52.86 & -5.74 \\
\hline B1 & 55.65 & -9.78 \\
\hline B2 & 52.67 & $-18,37$ \\
\hline D1 & 54.55 & -7.57 \\
\hline D2 & 49,21 & -12.44 \\
\hline
\end{tabular}

Catatan: Tanda (-) pada angka menunjukkan penurunan glukosa darah 
Keterangan:

$\Delta$ Glukosa Masa Hiperglikemik $=(\mathrm{MH}-\mathrm{MA}) / \mathrm{MH}$ $\mathrm{x} 100 \%$

$\Delta$ Glukosa Masa Perlakuan $=($ MP-MH $) / \mathrm{MP} x$ $100 \%$

Kadar glukosa darah tikus menunjukkan bahwa pemberian ekstrak bunga dan daun pepaya dengan dosis 12,6 dan $25,2 \mathrm{~g} / \mathrm{Kg} \mathrm{BB}$ memberikan efek antihiperglikemia untuk semua dosis. Persentase penurunan untuk bunga pepaya dengan dosis $150 ; 260 \mathrm{mg} / \mathrm{kg}$ BB adalah 9,78\%;18,37\% dan untuk daun pepaya $\quad 100 ; 170 \mathrm{mg} / \mathrm{kg} \quad \mathrm{BB}$ adalah 7,57\%;12,44\%. Kenaikan kadar glukosa darah pada hari ke-9 setelah pemberian aloksan $90 \mathrm{mg} / \mathrm{Kg}$ BB sebesar 52,80\%, dan terjadi penurunan kadar glukosa darah tikus untuk masing-masing kelompok setelah perlakuan ekstrak pada hari ke-12.

Kelompok perlakuan kontrol negatif yang diberikan sukrosa terjadi penuruan kadar glukosa darah sebesar $0,46 \%$ pada hari ke-12. Pemberian sukrosa dapat menyebabkan kondisi hiperglikemia disebabkan oleh penyerapan glukosa yang berlebih oleh tubuh sehingga masuk ke dalam darah. Konsumsi glukosa berlebih menyebabkan sel beta tidak dapat bekerja optimal menghasilkan insulin (Kondoy et al., 2013).

Kelompok perlakuan kontrol positif yang diberikan air terjadi penuruan kadar glukosa darah sebesar 5,74\%. Menurut LeBoy (2016), air putih dapat mengurangi resistensi insulin karena hidrasi yang tepat. Sementara minum air putih yang cukup juga mengurangi rasa lapar dan cenderung makan lebih sedikit pada siang hari, minum air putih yang cukup dapat membantu mengontrol kadar glukosa darah.

Ekstrak bunga pepaya pada dosis $260 \mathrm{mg} / \mathrm{Kg}$ BB menunjukkan penurunan kadar glukosa darah yang efektif terhadap persentase penurunan kadar glukosa darah pada hari ke-12 yaitu sebesar 18,37\% dibandingkan pada ekstrak bunga pepaya dengan dosis $150 \mathrm{mg} / \mathrm{Kg} \mathrm{BB}$ pada hari ke-12 yaitu sebesar 9,78\%. Begitu juga dengan ekstrak daun pepaya pada dosis $170 \mathrm{mg} / \mathrm{Kg}$ BB menunjukkan penurunan kadar glukosa darah yang efektif terhadap persentase penurunan kadar glukosa darah pada hari ke12 yaitu sebesar 12,44\% dibandingakan pada ekstrak daun pepaya dengan dosis $100 \mathrm{mg} / \mathrm{Kg}$ BB pada hari ke-12 yaitu sebesar 7,57\%. Hasil analisa penurunan kadar glukosa darah menunjukkan bawah pemberian ekstrak bunga pepaya dosis $260 \mathrm{mg} / \mathrm{Kg} \mathrm{BB}$ dan ekstrak daun pepaya dosis $170 \mathrm{mg} / \mathrm{Kg} \mathrm{BB}$ memberikan penurunan kadar glukosa darah yang paling baik dibandingkan ekstrak bunga pepaya dosis $150 \mathrm{mg} / \mathrm{kg} \mathrm{BB}$ dan ekstrak daun pepaya $\quad 100 \mathrm{mg} / \mathrm{Kg} \mathrm{BB}$.

Hal yang sama juga dikemukakan oleh Syah et al. (2015) dalam penelitian uji aktivitas antidiabetes ekstrak Ethanol daun mangga arumanis menjelaskan bahwa zat uji dalam bentuk ekstrak, mengandung senyawa aktif yang memiliki efek antidiabetes dengan adanya peningkatan dosisi maka akan berpengaruh pada peningkatan efek antidiabetes yang diberikan.

Kemampuan ekstrak bunga dan daun pepaya dalam menurunakan kadar glukosa darah tikus, diduga disebabkan oleh adanya kandungan zat aktif dalam daun pepaya yaitu flavonoid, dan tannin, berefek hipoglikemia. Selain itu, zat aktif yang terkandung dalam daun pepaya juga berperan merangsang pelepasan insulin dari sel beta pankreas dan pelepasan somatostatin tetapi menekan sekresi glukagon (Davis \& Granner, 2001). Hal ini dibuktikan oleh Wehantouw et al. (2011) yang meneliti aktivitas antihiperglikemik kulit buah manggis bahwa senyawa polifenol seperti flavonoid dan tanin dapat menurunkan kadar glukosa darah. Senyawa flavonoid merupakan senyawa antioksidan dan diduga mengembalikan sensitifitas reseptor insulin pada sel beta pankreas, sehingga menyebabkan penurunan kadar glukosa darah pada tikus (Saleh et al., 2012). 


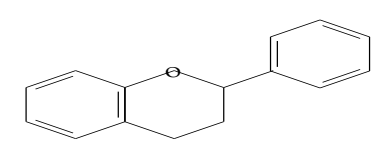

A
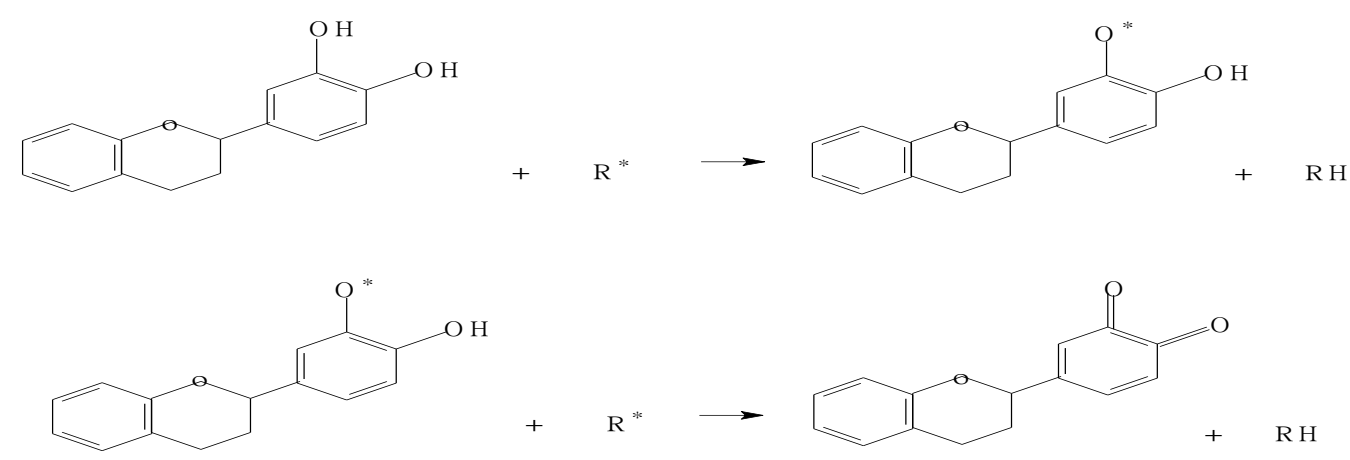

$\mathrm{B}$

Gambar 1. (A) Struktur Dasar Flavonoid (B) Peredaman Radikal Bebas oleh Flavonoid

(Yuhernita, 2011)

Menurut penelitian Qurrota \& Ainun (2015) analisis fitokimia daun pepaya mengandung senyawa metabolit sekunder; alkaloid, triterpenoid, steroid, flavonoid, saponin, dan tannin. Menurut Vijay et al. (2014) bunga pepaya mengandung senyawa metabolit sekunder seperti; allkaloid, flavonoid, saponin dan tannin. Menurut Salem (2009) Flavonoid merupakan antioksidan yang dapat mencegah reaksi pembentukan rantai (advanced glycosylation end products) AGE penyebab perubahan patologis pada keadaan hiperglikemik.

Sifat antioksidan dari flavonoid berasal dari kemampuan untuk mentransfer sebuah elektron ke senyawa radikal bebas dan juga membentuk kompleks dengan logam. Mekanisme kerja flavonoid dalam melindungi tubuh terhadap efek radikal bebas adalah dengan mengurai oksigen radikal, melindungi sel dari peroksidasi lipid, memutuskan rantai reaksi radikal, mengikat ion logam dari kompleks inert sehingga ion logam tersebut tidak dapat berperan dalam proses konversi superoxide radicals dan hidrogen peroksida menjadi radikal hidroksil, mengurangi peningkatan permeabilitas vaskuler pada saat peradangan, memblokade jalur sorbitol, menginhibisi aldose reduktase.

Senyawa alkaloid memiliki kemampuan untuk menghentikan reaksi rantai radikal bebas secara efisien. Senyawa radikal turunan dari senyawa amina ini memiliki tahap terminasi yang sangat lama. Menurut Abdelmoaty (2010) Alkaloid dan tanin juga dapat menghambat absorpsi glukosa di usus. Sehingga adanya flavonoid, alkaloid dan tannin memberikan efek yang menguntungkan pada keadaan diabetes melitus. 


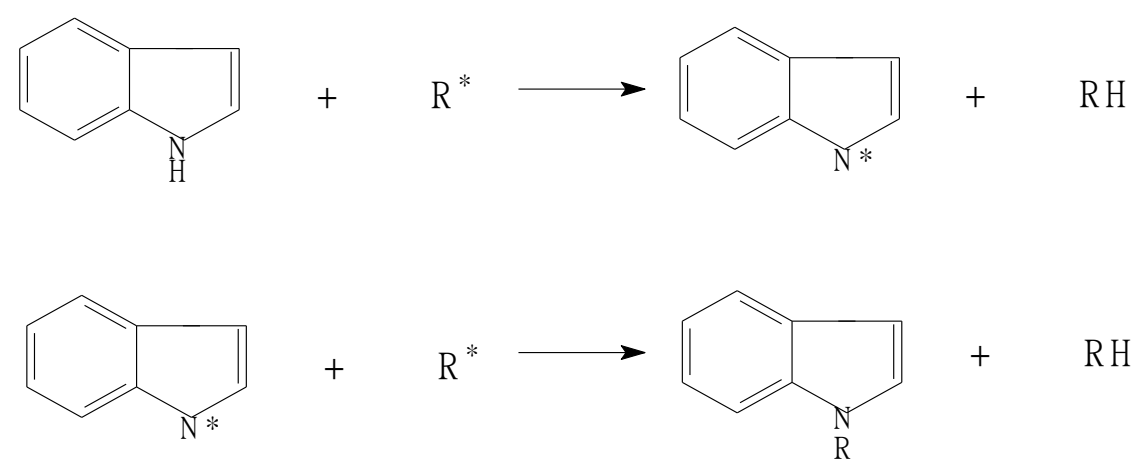

Gambar 2. Peredaman radikal bebas oleh alkaloid (Yuhernita, 2011)

Dari hasil statistika didapat perbedaan antara kelompok perlakuan kontrol negatif $(\mathrm{K}+)$ dan kelompok perlakuan ekstrak bunga (B) dan daun pepaya (D) sedangkan kelompok perlakuan kontrol positf (K-) tidak. Kelompok perlakuan ekstrak bunga pepaya dosis $\quad 260 \mathrm{mg} / \mathrm{Kg} \mathrm{BB}$ pada hari ke-12 menunjukkan dosis yang efektif diantara kelompok perlakuan ekstrak bunga pepaya dosis $150 \mathrm{mg} / \mathrm{Kg} \mathrm{BB}$. Kelompok perlakuan daun pepaya dosis $170 \mathrm{mg} / \mathrm{Kg} \mathrm{BB}$ pada hari ke-12 menunjukkan dosis yang efektif diantara kelompok perlakuan ekstrak daun pepaya dosis $100 \mathrm{mg} / \mathrm{Kg}$ BB. Hal ini menunjukkan bahwa dosis ekstrak Ethanol bunga pepaya $260 \mathrm{mg} / \mathrm{Kg} \mathrm{BB}$ dan dosis ekstrak etanol daun pepaya $170 \mathrm{mg} / \mathrm{Kg} \mathrm{BB}$ memiliki aktifitas dalam menurunkan kadar glukosa darah pada tikus jantan Wistar yang hiperglikemik.

\section{KESIMPULAN DAN SARAN}

\section{Kesimpulan}

Pemberian ekstrak Ethanol bunga dan daun pepaya (Carica Papaya L.) berpengaruh terhadap penurunan kadar glukosa darah tikus wistar (Ratus Norvegicus L) yang Hiperglikemik Dosis ekstrak bunga dan daun pepaya yang efektif dalam menurunkan kadar glukosa darah tikus yang hiperglikemia akibat diinduksi dengan aloksan adalah dosis ekstrak bunga pepaya $260 \mathrm{mg} / \mathrm{Kg} \mathrm{BB}$ dan dosis ekstrak daun $170 \mathrm{mg} / \mathrm{Kg}$ BB atau setara dengan bunga dan daun pepaya basah $200 \mathrm{~g}$.
Perlu dilakuan isolasi dan karakteristik terhadap senyawa aktif antihiperglikemik pada ekstrak bunga dan daun pepaya untuk penelitian selanjutnya.

\section{DAFTAR PUSTAKA}

Abdelmoaty, M. A., Ibrahim, M. A., Ahmed, N. S., \& Abdelaziz, M.A. 2010. Confirmatory Studies on the Antioxidant and Antidiabetic Effect of Quercetin in Rats. Indian. Clinical Biochemistry Journal. 25:188-192.

Ayoola P. B. \& Adeyeye. A. 2010. Phytochemical and Nutrient Evaluation of Carica papaya (Pawpaw) Leaves. Intenational Journal of Reaserch Review. 5: 325-328.

Corwin, E. J. 2009. Buku Saku Patofisiologi Edisi Ke-3. Kedokteran EGC, Jakarta.

Davis, S. N. \& Granner, D. K. 2001. Insulin, oral hypoglicemic agents, and thepharmacology of the endocrine pancreas. In : Goodman and Gilman's the pharmalogical basis of therapeutics, 10th ed. McGraw-Hill, New York.

Depkes RI . 1995. Materia Medika Indonesia Jilid VI. Direktorat Jenderal Pengawasan Obat Dan Makanan, Jakarta.

Helrich, K. 1999. Official Methods of Analysis of Association of Official Analitical Chemists. 15th Edition. Association of Official Analytical Chemist, USA.

\section{Saran}


Indrawati, Y., Kosasih, Soetarno, S., \& Gana, S. A. (2002). Telaah Fitokimia Bunga Pepaya Gantung (Carica papaya L.) dan Uji Aktivitas Antioksidannya. http://bahan-alam.fa.itb.ac.id/ detail.php?id=69. [14 Maret 2017].

LeBoy, E. 2016. Endocrinology Diabetes \& Metabolism.https ://www .sharecare. com/health/diabetes/drinking -water blood-sugar. [14 Juli 2017].

Kanon, M. Q., Fatimawali., \& W. Bodhi. 2012. Uji Efektivitas Ekstrak Kulit Buah Salak (Salacca zalacca (Gaertn.) Voss) terhadap Penurunan Kadar Gula Darah Tikus Putih Jantan Galur Wistar (Rattus norvegicus L.) yang Diinduksi Sukrosa. International Journal of Pharmacon. 1: 52-58.

Kondoy, S., Wullur, A., \& Dodhi, W. 2013. Potensi Ekstrak Etanol Daun Kayu Manis (Cinnamomum burmanii) terhadap Penurunan Kadar Glukosa Darah dari Tikus Putih Jantan (Rattus norvegicus) yang Diinduksi Sukrosa. Pharmacon. 2: 96-99.

Latifah, H., \& Syahrial. 2007. Isolasi Dan Identifikasi Steroid Pada Bunga Pepaya (Carica Papaya L.) Jantan.http://www.rp2u.unsyiah.ac.id/ind ex.php/welcome/prosesDownload/666/4. [16 Maret 2017].

Maliangkay, D. M. 2016. Uji Efektifitas Antidiabetes Ekstrak Etanol Kulit Buah Manggis (Gracinia mangostana L.) pada Tikus Putih (Rattus norvegicus) yang Diinduksi Aloksan. [Tesis]. Program Pascasarjana Prodi Biologi, Universitas Negeri Manado.

Mahatriny, N. N., Payani, N. P. S., Oka, I. B. M., \& Astuti, K. W. 2014. Skrining Fitokimia Ekstrak Etanol Daun Pepaya (Carica papaya L.) yang Diperoleh dari Daerah Ubud, Kabupaten Gianyar, Bali.http://scribd.zxcv.website/document/ 270795605/ekstrak-etanol-pdf. [14 Maret 2017].

Murray, R. K., Granner, D. K., \& Rodwell, V. W. 2009. Biokimia Harper Edisi ke27. Kedokteran EGC, Jakarta.
Prameswari, O. M. \& Widjanarko, S. B. 2014. Uji Efek Ekstrak Air Daun Pandan Wangi terhadap Penurunan Kadar Glukosa Darah dan Histopatologi Tikus Diabetes Mellitus. Jurnal Pangan \& Agroindustri. 2:16-27.

Qurrota A., \& Ainun N. L. 2015. The Phytochemical Analysis of Papaya Leaf (Carica papaya L.). Journal of Chemistry. 20: 134-137.

Salem, A.O.M. 2009. Experimental Diabetic Nephropathy Can Be Prevented by Propolis: Effect on Metabolic Distrubances \& Renal Oxidative Parameters. Pharmacology \& Toxicology Departement \& Biochemistry Department, Cairo.

Salma, S., Paendong, J., Momuat, L. I., \& Togubu, S. 2013. Antihiperglikemik Ekstrak Tumbuhan Suruhan (Peperomia pellucida [L.] Kunth) Terhadap Tikus Wistar (Rattus norvegicus L.) Yang Diinduksi Sukrosa. Jurnal Ilmiah Sains. 2: 116-123.

Samuelsson, G. 1999. Drug of Natural Origin, a Text Book of Pharmacognosy. Swedish Pharmaceutical Press, Stockholm.

Shuldiner, A. R. 2001. Resistin, Obesity, and Insulin Resistance - The Emerging Role of the Adipocyte as an Endocrine Organ. New England Journal of Medicine. 18: $1345-1356$.

Suarsana, I. N., Priosoeryanto, B. P., Bintang, M., \& Wresdiyati, T. 2008. Aktivitas Daya Hambat Enzim $\alpha$-Glukosidase dan Efek Hipoglikemik Ekstrak Tempe pada Tikus Diabetes. Journal Veteriner. 3:122127.

Sudjana. 1996. Metoda Statistika. Tarsito Bandung, Bandung.

Sukandar, E.Y., Andrajati, R., Sigit, J. I., Adnyana, I. K., Setiadi, A. A., \& Kusnandar. 2008. Isofarmakoterapi Edisi Pertama. Penerbit PT. ISFI, Jakarta.

Syah, I, S., Suwendar, \& Mulqie, L. 2015. Uji Aktivitas Antidiabetes Ekstrak Etanol Daun Mangga Arumanis (Mangifera Indica L. "Arumanis") pada Mencit Swiss Webster Jantan dengan Metode Tes Toleransi Glukosa Oral (Ttgo). Jurnal Scientica UNSIBA. 2:297-303. 
Szkudelski, T. 2001. The Mechanism Of Alloxan And Streptozotocin Action In $\beta$ Cells Of The Rat Pancreas. Physiology Research. 50: 54-536.

Taguchi, Y. 1985. Experimental Animals. Clea Japan Inc., Tokyo.

Tresna, E. P. 2012. Aktivitas Antidiabetes Ekstrak Air dan Ethanol Daun Sirsak SecaraIn Vitro melalui Inhibisi Enzim $\alpha$ Glokosidase. [Skripsi]. Fakulutas Matematika dan Ilmu Pengetahuan Alam, Isntiut Pertanian Bogor.

Vijay, Y., Pradeep K. G., Chetan S. C., Anju G., \& Bhupendra Vyas. 2014. Carica papaya Linn: An Overview. International Journal of Herbal Medicine. 2: 01-08.
Wahentouw, F., Manurung, S., \& Suryanto, E. 2011. Aktivitas Antihiperglikemik Ekstrak Kulit Manggis (Garcinia Mongostana L.) pada Tikus ang Diinduksi Aloksan. Chemistry Progress Journal. 2: 89-96.

Yuhernita. 2011. Analisis Senyawa Metabolit Sekunder dari Ekstrak Metanol Daun Surian yang Berpotensi sebagai Antioksidan. Fakultas Kedokteran Universitas Yasri, Jakarta. 